Check for updates

Cite this: RSC Adv., 2018, 8, 28376

Received 5th June 2018

Accepted 27th July 2018

DOI: $10.1039 / \mathrm{c} 8 \mathrm{ra04802a}$

rsc.li/rsc-advances

\section{Preparation of prolinamide with adamantane for aldol reaction catalysis in brine and separation using a poly(AN-MA- $\beta-C D)$ nanofibrous film via host-guest interaction $\uparrow$}

\author{
Rui Wang, ${ }^{a}$ Enjie $\mathrm{Xu},{ }^{a}$ Zhenming Su, ${ }^{\mathrm{b}}$ Haifeng Duan, ${ }^{\mathrm{a}}$ Jinjin Wang, ${ }^{\mathrm{a}}$ Longqi Xue, ${ }^{\mathrm{a}}$ \\ Yingjie Lin, (D) ${ }^{a}$ Yaoxian $\mathrm{Li}^{a}{ }^{a}$ Zhonglin $\mathrm{Wei}^{\mathrm{a}}$ and Qingbiao Yang (D) *a
}

Prolinamides with double- $\mathrm{H}$ potential were prepared and employed as organocatalysts in asymmetric aldol reactions. The catalyst with adamantane showed improved catalytic activity, which was further enhanced by using brine as the solvent. A series of aldol reactions in brine at $0{ }^{\circ} \mathrm{C}$ provided good yields (up to $98 \%$ ) with high diastereoselectivities (>99:1) and enantioselectivities (>99\%). The prepared catalyst was adsorbed by a nanofibrous film of poly(AN-MA- $\beta-C D$ ) via host-guest interaction in the reaction system. The catalyst was separated from the film by applying ultrasound, with a total recovery of $96.2 \%$. The catalyst was reused up to five times without a significant change in diastereoselectivity and enantioselectivity.

\section{Introduction}

Asymmetric aldol reactions play an important role in carboncarbon bond forming reactions. The design and synthesis of small molecule organocatalysts based on L-proline have been given considerable attention after List and co-workers reported the s-proline-catalyzed direct aldol reaction. ${ }^{1}$ In the s-prolinecatalyzed reaction, the necessity of using the carboxylic acid of proline remains unclear. Since Tang and co-workers reported prolinamide-catalyzed aldol reactions of 4-nitrobenzaldehyde with acetone, ${ }^{2}$ effective organocatalysts have been developed based on proline to afford facile atom economic access to optically pure compounds. ${ }^{3}$ In 2010, Moorthy demonstrated the use of double-H potential catalysts based on L-proline and $o$ phenylenediamine to catalyze the aldol reaction of $p$-nitrobenzaldehyde with cyclohexanone in DMF in the presence of TFA with desirable yield (94\%), stereoselectivity ( $>98 \%)$, and diastereoselectivity $(97: 3){ }^{4}$ Yang et al. used benzyl chloride instead of nitrobenzene sulfonic acid to synthesize prolinamide catalysts, which resulted in faster reactions with good diastereoselectivity in brine at room temperature. ${ }^{3}$ Nonetheless, the asymmetric reactions are usually conducted in organic solvents, such as DMF, DMSO, PhMe, and MeCN. To promote the use of environmentally friendly solvents for catalytic reaction, inorganic systems are desired as solvents. ${ }^{5}$ Switching organic

${ }^{a}$ College of Chemistry, Jilin University, 2699 Qianjin Street, Changchun 130012, P. R. China. E-mail: yangqb@jlu.edu.cn

${ }^{b}$ Security Check, Jilin Province, 566B Guigu Street, Changchun 130012, P. R. China

$\dagger$ Electronic supplementary information (ESI) available. See DOI: $10.1039 / \mathrm{c} 8 \mathrm{ra} 04802 \mathrm{a}$ solvents to water offers low cost, safety, and environmentally benign nature. ${ }^{6}$ Since Breslow reported that the acceleration of Diels-Alder reaction in water, there is a surge of interest in using water as reaction medium. ${ }^{7}$

Recycling catalysts decreases the consumption of auxiliary substances in obtaining pure catalyst, leading to significant economic and environmental benefits. ${ }^{8}$ To realize recyclability of catalyst, researchers have focused on immobilizing catalysts on diverse solid supports. ${ }^{9}$ So far, nanoparticles and polymers have been used support, from which catalysts can be recovered and reused after centrifugation, magnetic decantation or filtration..$^{10}$ However, a general and conventional method for immobilizing different types of organocatalysts considering stability, reactivity, and recyclability of the obtained heterogeneous materials has not been established. ${ }^{11}$ Moreover, supported catalysts for heterogeneous catalysis generate poor yield and stereoselectivity. Compared with supported heterogeneous catalysts, homogeneous ones provide many advantages in catalytic reaction. Nevertheless, recycling catalysts has obvious shortcomings, such as large consumption, difficult separation, and high cost. Hence, the concept wherein reaction is conducted in homogeneous medium and catalyst is recovered in heterogeneous system is highly beneficial to the development of environmentally friendly catalytic reactions. The design of selfassembled aggregates that employ host-guest interactions choosing geometrically complementary host and guest molecules is an important method of physical adsorption. ${ }^{12}$ Previously, we reported that assembly and separation of small organic molecules were driven by adamantane and $\beta$-cyclodextrin $(\beta-\mathrm{CD})$ via host-guest interaction. ${ }^{13}$ The recovery of organocatalysts via host-guest interactions could solve a traditional 
problem regarding heterogeneity of solid-supported catalyst. ${ }^{14}$ We reported the aldol product of $p$-nitrobenzaldehyde with cyclohexanone in toluene at $-20^{\circ} \mathrm{C}$ was separated by $\alpha$-CD from the reaction system in Scheme $1 .{ }^{15}$ However, $\alpha$-CD being easy to dissolve in water is to the disadvantage of the overall recycling of the product. Therefore, the developing the water insoluble $\alpha$ $\mathrm{CD}$ or $\beta$-CD is of the essence.

Herein, we synthesize adamantine-modified catalysts separated by supported $\beta$-CD via host-guest interaction. $O$ phenylenediamine catalysts with double hydrogen potential based on L-proline or trans-4-hydroxy-L-proline were synthesized to catalyze aldol reactions of ketone and aldehyde (Fig. 1). Prolinamides with 1-adamantane carboxylic acid could improve the catalytic activity by replacing benzoic acid. Improved results were obtained by switching the solvent to an inorganic system. The brine was used as medium at $0{ }^{\circ} \mathrm{C}$ for catalyzing the aldol reaction of aldehyde and ketone, resulting in excellent yields with good stereoselectivity and diastereoselectivity. $\beta$-CD-modified polymer (poly(AN-MA- $\beta$-CD)) was synthesized by using co-polymer (poly(AN-MA)) and $\beta$-CD, and then nanofibrous film was prepared by electrospinning. A flowchart of catalyst separation from the film is described in Scheme 2. After each run, the catalyst could be adsorbed by the film via host-guest interaction in the reaction system and separated by washing with $\mathrm{MeOH}$ under ultrasound from the film.

Our previous work

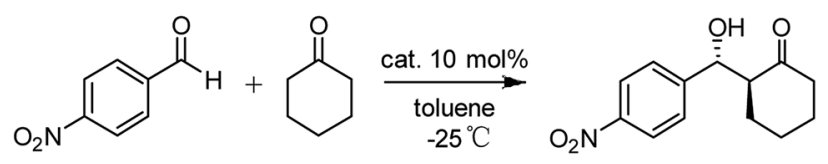

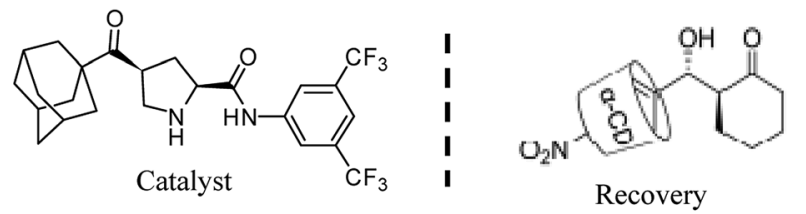

This work
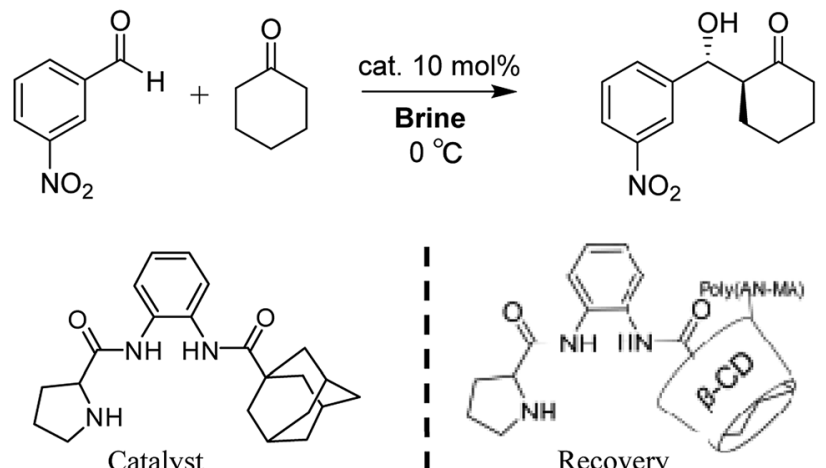

Catalyst

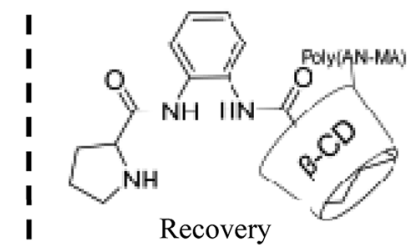

Scheme 1 Adamantane-modified organocatalysts for asymmetric aldol reactions and recovery of the catalysts.

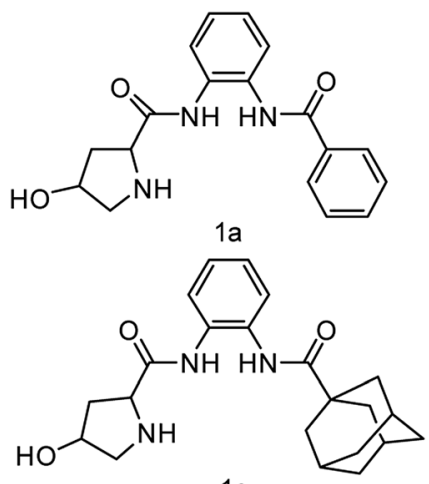

$1 c$

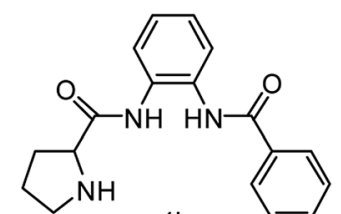

$1 b$

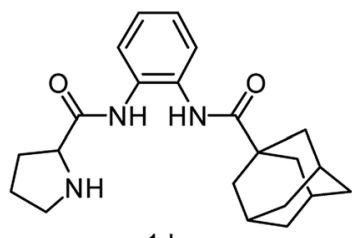

$1 d$
Fig. 1 Adamantane-modified prolinamide catalysts.

\section{Results and discussion}

\section{Asymmetric aldol reaction}

Initially, we employed chiral prolinamide catalysts 1a-1d to screen the direct aldol reaction of $p$-nitrobenzaldehyde with cyclohexanone at room temperature (Scheme 2). A series of experiments were then performed under different reaction conditions (different catalysts, loading, and solvents). The results are summarized in Table 1 . In the beginning of the experiment (Table 1, entries 1-4), the reactions were catalyzed by different prolinamides $(10 \mathrm{~mol} \%)$ at room temperature for $36 \mathrm{~h}$ in DCM. Interestingly, all catalysts provided the desired aldol products with good yields. The aldol reactions in the presence of prolinamides $\mathbf{1 a}$ and $\mathbf{1 b}$ generated $69 \%$ and $77 \%$ of enantioselectivity (Table 1, entries 1 and 2). When used to catalyze the aldol reaction of 4-nitrobenzaldehyde and cyclohexanone, compounds 1c and 1d afforded good yields with higher diastereoselectivity and enantioselectivity than $\mathbf{1 a}$ and 1b. This result may be due to replacement of benzoic acid with the large steric hindrance of adamantane. Compared with compound 1c, the desired product was formed in $91 \%$ yield with $89 \%$ stereoselectivity when catalyst 1d was employed (Table 1, entry 4). Compared to results reported respectively by Moorthy' and Yang' research groups, the catalyst 1d improves the catalytic activity. Our group have reported that the adamantine provided by 4 -substitution position based on $\mathrm{L}^{-}$ proline played an important role in diastereoselectivity and enantioselectivity. ${ }^{15}$ In addition, catalysts with adamantyl group were employed in other asymmetrical reactions provided good diastereoselectivity or enantioselectivity. ${ }^{\mathbf{1 4 1 6}}$ Although catalyst loading was varied from $10 \mathrm{~mol} \%$ to $30 \mathrm{~mol} \%$, no further improvement in diastereoselectivity and enantioselectivity was observed (Table 1 entries 4-6). Poor diastereoselectivity was obtained at low catalyst loading of $5 \mathrm{~mol} \%$ or $2 \mathrm{~mol} \%$ (Table 1 , entries 7-8). Considering that the catalyst 1d of $10 \mathrm{~mol} \%$ afforded a good conversion with desirable diastereoselectivity and enantioselectivity, entry 4 was selected as an optimal reaction. Compound $\mathbf{1 d}$ of $10 \mathrm{~mol} \%$ was employed as catalyst in nine solvents with different polarities at room temperature for $36 \mathrm{~h}$ of reaction under vigorous stirring. The aldol reactions being conducted in nine solvents investigated showed no 


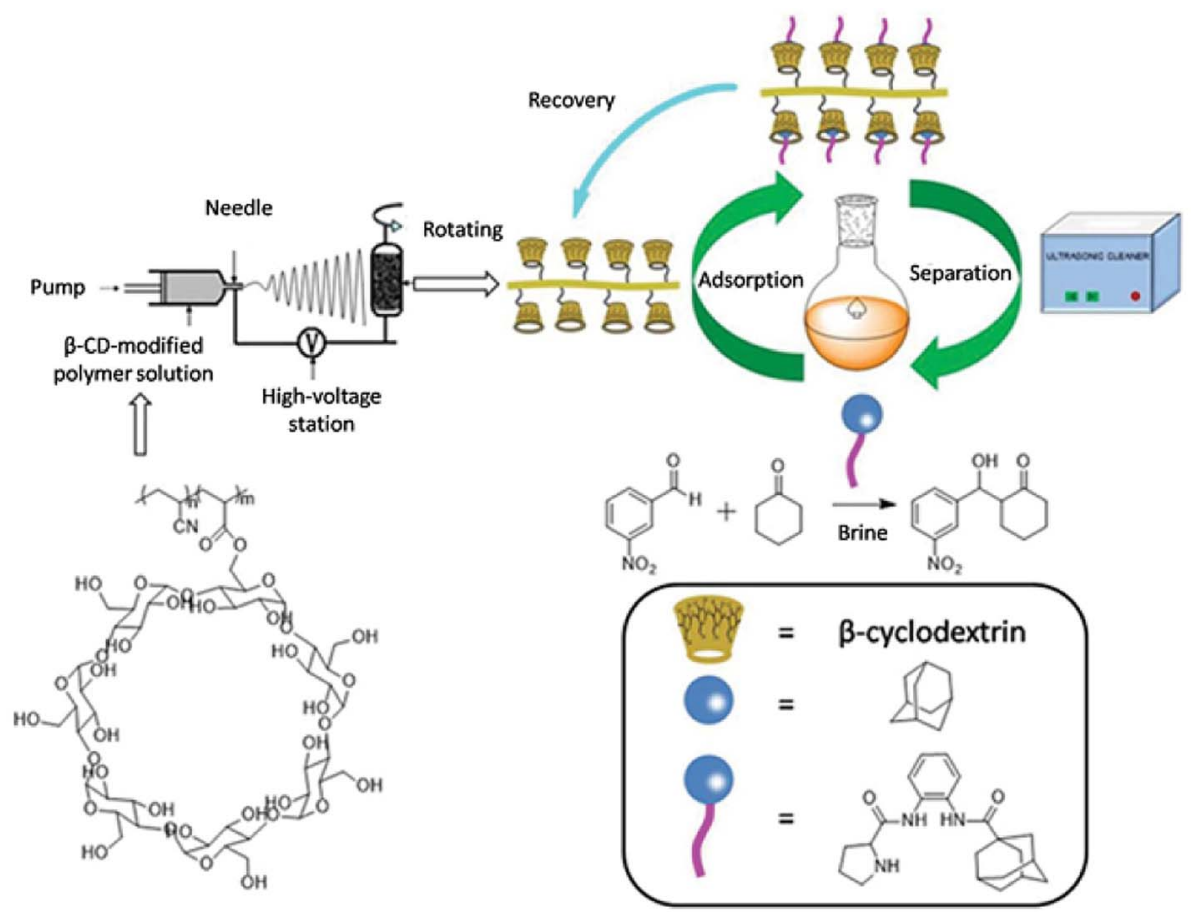

Scheme 2 Illustration for recyclability of catalyst.

significant change in yield (from $90 \%$ to $96 \%$ ) and diastereoselectivity (from $96: 4$ to $99: 1$ ). However, the stereoselectivity was significantly influenced on ranging from $82 \%$ $(\mathrm{MeOH})$ to $95 \%$ (brine). Among the seven other organic solvents, high stereoselectivity (91\%) was obtained when THF was used as solvent (Table 1, entry 9). Compared with organic solvents, the inorganic medium was found to be superior in terms of stereoselectivity. For example, brine provided the best stereoselectivity of the aldol product (95\%) to proved itself be

Table 1 Screening catalysts and solvents ${ }^{a}$

\begin{tabular}{rllllll}
\hline Entry & Catalyst & Mol\% & Solvent & Yield $^{b}(\%)$ & $\mathrm{dr}^{c}($ anti/syn $)$ & $\mathrm{ee}^{c}(\%)$ \\
\hline 1 & 1a & 10 & DCM & 89 & $91: 9$ & 69 \\
2 & 1b & 10 & DCM & 96 & $88: 12$ & 77 \\
3 & 1c & 10 & DCM & 93 & $97: 3$ & 82 \\
4 & 1d & 10 & DCM & 91 & $97: 3$ & 89 \\
5 & 1d & 20 & DCM & 93 & $97: 3$ & 89 \\
6 & 1d & 30 & DCM & 96 & $97: 3$ & 89 \\
7 & 1d & 5 & DCM & 90 & $95: 5$ & 88 \\
8 & 1d & 2 & DCM & 85 & $95: 5$ & 88 \\
9 & 1d & 10 & THF & 95 & $97: 3$ & 91 \\
10 & 1d & 10 & HEX & 94 & $99: 1$ & 86 \\
11 & 1d & 10 & EtOAc & 96 & $99: 1$ & 87 \\
12 & 1d & 10 & MeCN & 90 & $96: 4$ & 86 \\
13 & 1d & 10 & MeOH $^{d} 92$ & $99: 1$ & 82 \\
14 & 1d & 10 & DMSO & 92 & $98: 2$ & 86 \\
15 & 1d & 10 & $\mathrm{H}_{2} \mathrm{O}$ & 91 & $97: 3$ & 90 \\
16 & 1d & 10 & Brine $^{e}$ & 95 & $98: 2$ & 95
\end{tabular}

${ }^{a}$ Reaction conditions: $p$-nitrobenzaldehyde $(0.5 \mathrm{mmol})$, cyclohexanone (10 equiv.), solvent $(1.0 \mathrm{~mL})$, room temperature, 36 hours with vigorous stirring. ${ }^{b}$ Combined yields of isolated. ${ }^{c}$ Determined by HPLC with a chiral AD-H column. ${ }^{d} n$-hexane. ${ }^{e}$ Solubility of $20 \%$. the best (Table 1, entry 16). Therefore, brine was employed as solvent in further study.

To optimize the reaction conditions, we determined the effect of acid additive ${ }^{17}$ and reaction temperature. ${ }^{18}$ The most relevant results were detailed in Table 2 . As indicated by entries 1-5 in Table 2, $10 \mathrm{~mol} \%$ organic acid (such as 4-nitrobenzoic acid, benzoic acid, trifluoroacetic acid, acetic acid and methanolic acid) was added to the reaction in brine at room temperature for $36 \mathrm{~h}$. When the reactions were carried out in the presence of an organic acid, the yields were slightly improved, while diastereoselectivity and stereoselectivity showed no significant differences. A high efficiency was obtained when no additive was added to the reaction mixture (Table 2 , entry 6 ). In

Table 2 Screening additive and temperature ${ }^{a}$

\begin{tabular}{llllll}
\hline Entry & Additive & $T\left({ }^{\circ} \mathrm{C}\right)$ & Yield $^{b}(\%)$ & $\mathrm{dr}^{c}$ (anti/syn) & $\mathrm{ee}^{c}(\%)$ \\
\hline 1 & $4-\mathrm{NO}_{2} \mathrm{PhCOOH}$ & $\mathrm{rt}$ & 98 & $97: 3$ & 94 \\
2 & $\mathrm{PhCOOH}_{3}$ & $\mathrm{rt}$ & 98 & $96: 4$ & 95 \\
3 & $\mathrm{CF}_{3} \mathrm{OOH}$ & $\mathrm{rt}$ & 96 & $96: 4$ & 93 \\
4 & $\mathrm{CH}_{3} \mathrm{OOH}$ & $\mathrm{rt}$ & 95 & $95: 5$ & 94 \\
5 & $\mathrm{HCOOH}$ & $\mathrm{rt}$ & 96 & $95: 5$ & 93 \\
6 & - & $\mathrm{rt}$ & 95 & $98: 2$ & 95 \\
7 & - & 10 & 95 & $98: 2$ & 95 \\
8 & - & 0 & 93 & $98: 2$ & 96 \\
$9^{d}$ & - & 0 & 98 & $98: 2$ & 96
\end{tabular}

${ }^{a}$ Reaction conditions: $p$-nitrobenzaldehyde $(0.5 \mathrm{mmol})$, cyclohexanone (10 equiv.), catalyst $1 \mathrm{~d}(0.05 \mathrm{mmol}, 10 \mathrm{~mol} \%)$, solvent $(1.0 \mathrm{~mL})$, room temperature, 36 hours with vigorous stirring. ${ }^{b}$ Combined yields of isolated. ${ }^{c}$ Determined by HPLC with a chiral AD-H column. ${ }^{d}$ Vigorous stirring for 48 hours. 
an effort to improve the catalytic activity, the reaction temperature further was investigated. By lowering the reaction temperature to $10{ }^{\circ} \mathrm{C}$, the reaction went smoothly to form the desired aldol product without significant change in diastereoselectivity and stereoselectivity. A further reduced of the reaction temperature to $0{ }^{\circ} \mathrm{C}$, a slight increase of stereoselectivity was observed. Lengthening reaction time to $48 \mathrm{~h}$ drove the reaction towards completion (yield 98\%). Entry 9 was performed under the optimized reaction conditions.

After determining the optimal reaction conditions, we further explored the substrate scope of aldol reactions; the results are summarized in Table 3 . In the initial experiment, aldol reactions of cyclohexanone with different aldehydes were investigated at $0{ }^{\circ} \mathrm{C}$. Satisfactorily, reactions gave the desired products in good yields with high diastereoselectivity and enantioselectivity. Benzaldehydes substituents with different electronic characters were studied, including electronicwithdrawing $\left(\mathrm{NO}_{2}, \mathrm{CN}, \mathrm{CF}_{3}, \mathrm{Cl}, \mathrm{Br}\right.$ and $\left.\mathrm{F}\right)$, electronic-neutral $(\mathrm{H})$ and electronic-donating $\left(\mathrm{OCH}_{3}\right.$ and $\left.\mathrm{CH}_{3}\right)$ groups. Aromatic aldehydes with ortho-, meta-, and para-substituents generated aldol products with similar yields. Aromatic aldehydes with strong electronic-withdrawing group underwent aldol reactions to provide the corresponding products in excellent yields with high diastereoselectivity and enantioselectivity (Table 3, entries 1-7). Moderate conversions were obtained by benzaldehydes with weak electronic-withdrawing and electronic-neutral groups (Table 3, entries 8-16). Compared to benzaldehyde, 2-naphthaldehyde provides poor diastereoselectivity and enantioselectivity. Aldehydes with electronic-donating were found to have very low reactivity and generated aldol products in $<10 \%$ yield (Table 3, entries 17-19). Ketone with different substituents were then investigated. In contrast to the aldehyde substrates, poor diastereoselectivity was produced by cyclopentanone (Table 3 , entry 20). When 2-butanone as reagent led to the formation of regioisomers, three pairs of enantiomers were obtained with poor enantioselectivities (Table 3, entry 21). Influenced by water hydrolyzing and steric hinderance, 2-butanone was easily transformed into stable carbanion. Therefore, the aldol product with one pair of enantiomer was dominant of 3-pentone. The aldol reaction in the presence of acetone also provided moderate yield with poor enantioselectivity (Table 3, entry 22). Enantioselectivities of large-scale asymmetric aldol reactions were reduced because a lot of aldehyde did not dissolve in brine under unevenly stringing.

Table 3 Scope for aldol reaction of ketones with aldehydes employing catalyst $1 \mathbf{d}^{a}$
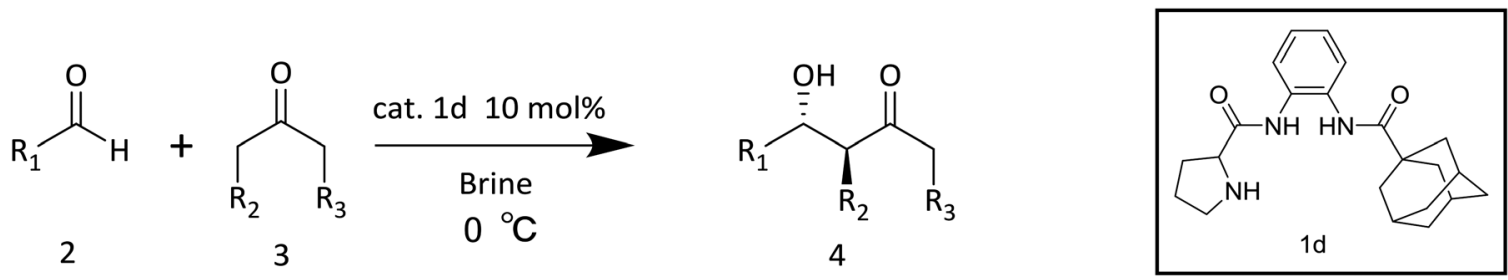

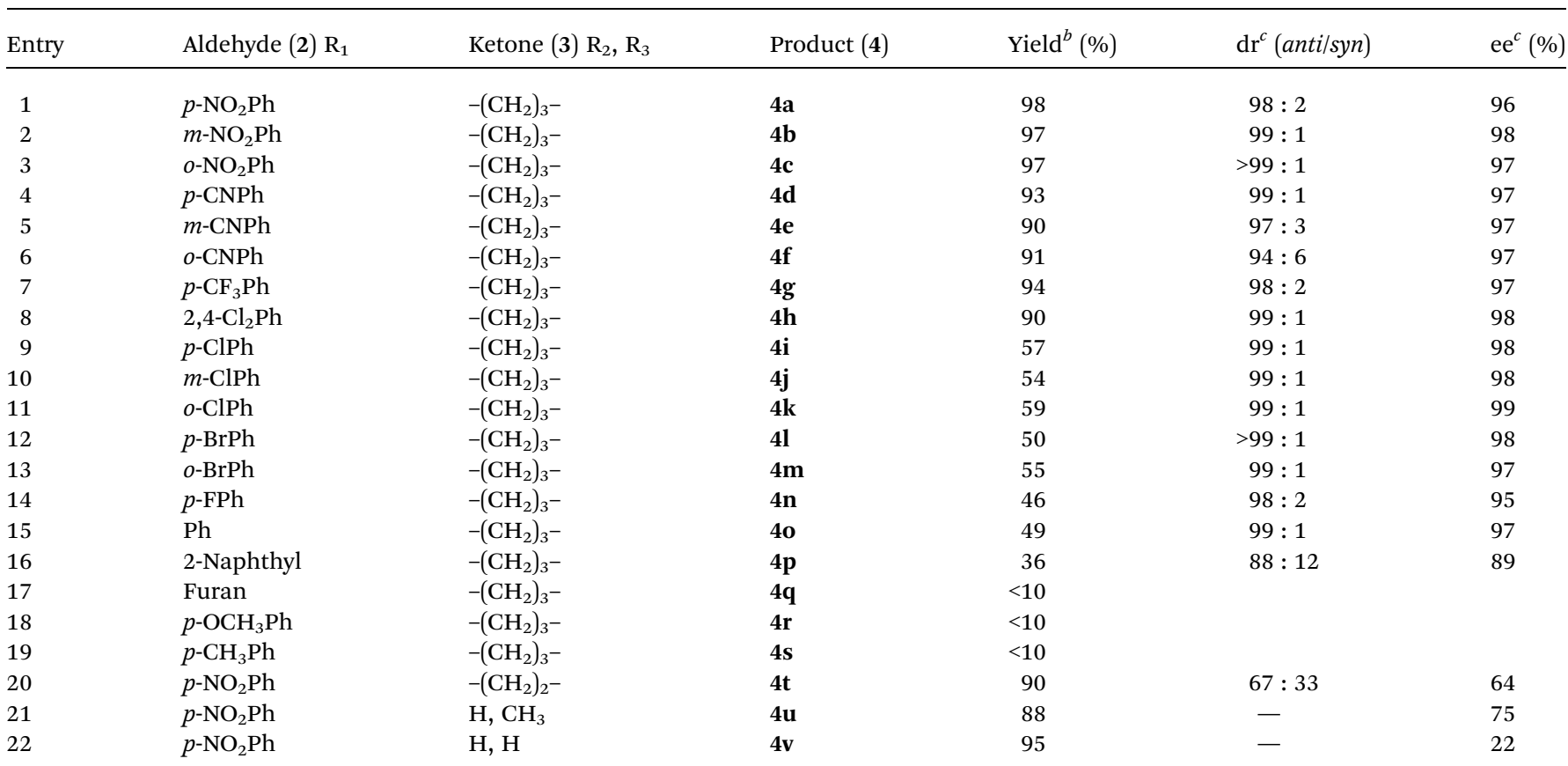

${ }^{a}$ Reaction conditions: aldehyde ( $\left.0.5 \mathrm{mmol}\right)$, ketone (10 equiv.), catalyst $1 \mathrm{~d}$ ( $\left.0.05 \mathrm{mmol}, 10 \mathrm{~mol} \%\right)$, solvent $(1.0 \mathrm{~mL})$, vigorous stirring with correspond time. ${ }^{b}$ Combined yields of isolated. ${ }^{c}$ Determined by HPLC with chiral AD-H column, chiral OD-H column and chiral AS-H column. 


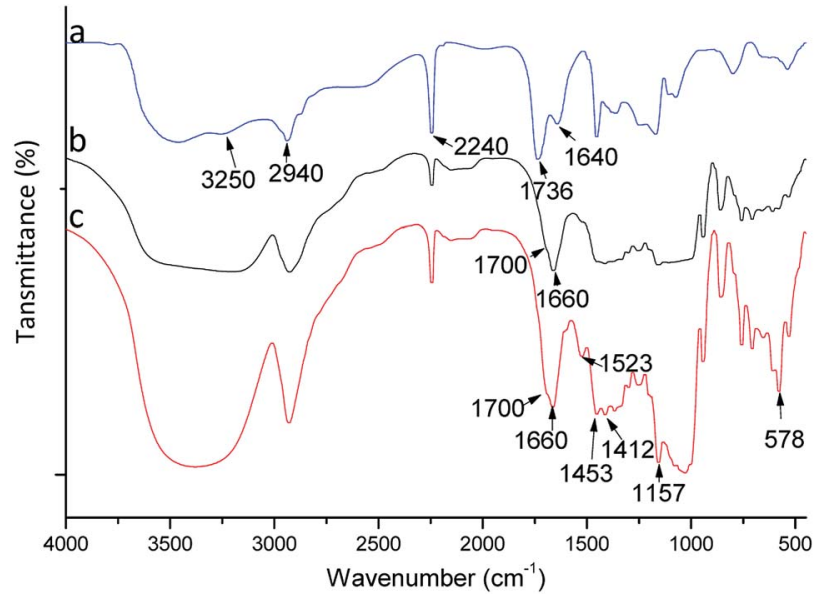

Fig. 2 FTIR spectra of poly(AN-MA) (a), poly(AN-MA- $\beta-C D)$ (b) and catalyst into poly(AN-MA- $\beta-C D)$ (c)

\section{FTIR analysis}

To confirm the composition and grafting, polymers were studied by FTIR spectroscopy (Fig. 2). A FTIR spectrum for poly(AN-MA) is shown in Fig. 2(a). Fig. 2(a) exhibits peaks at 2940 and $2240 \mathrm{~cm}^{-1}$, which were attributed to asymmetric $\mathrm{C}-\mathrm{H}$ stretching from $\left(-\mathrm{CH}_{2}-\right)_{n}$ and asymmetric $\mathrm{C}-\mathrm{N}$ stretching from cyano group. The characteristic peak of cyano group could be observed in Fig. 2(b) and (c). The broad peak at $3340 \mathrm{~cm}^{-1}$ was the symmetric -OH stretching from $\beta$-CD molecule in Fig. 2 (b), which could prove that $\beta$-CD was grafted on the polymer surface. In Fig. $2(\mathrm{c})$, the characteristic peaks of benzene framework vibration peaks can be observed at 1523,1453 , and $1412 \mathrm{~cm}^{-1}$. These bands, however, are not present in Fig. 2(a) and (b). Thus, the catalyst could successfully bind into poly(AN-MA- $\beta-\mathrm{CD})$.

\section{SEM analysis}

Typical SEM images of nanofibrous films of poly(AN-MA- $\beta$-CD) are shown in Fig. 3. It could be clearly seen that the membranes were composed of numerous and randomly oriented nanofibers. When the mass fraction of poly(AN-MA- $\beta$-CD) in DMF was $<20 \%$, a fibrous membrane was not formed. At mass fraction of $>36 \%$, poly(AN-MA- $\beta$-CD) did not dissolve in DMF in a short time. The SEM images showed that this membrane feature was affected by the mass fraction from $20 \%$ to $36 \%$ (Fig. 3). Fig. 3(a) and (b) showed that the nanofibrous film have an average diameter of exceed $1 \mu \mathrm{m}$. With further reduction in the mass fraction, the diameter of the resulting fibrous membranes (Fig. 3 (c)-(e)) had decreased. In particular, Fig. 3(c) and (d) respectively show an average diameter of about $440 \mathrm{~nm}$ and $430 \mathrm{~nm}$ with smooth surfaces. At mass fraction of $20 \%$, the average diameter of the film was approximately $160 \mathrm{~nm}$ with smooth surface (Fig. 3(e)). In general, 20\% poly(AN-MA- $\beta$-CD) formed plentiful fibrous membranes. Compared with Fig. 3(e), the result in Fig. 3(f) showed coarser surfaces and larger diameter.

\section{Recyclability of catalyst}

In the next moment, we further evaluated the recyclability of the catalyst in the direct aldol reactions. According to related

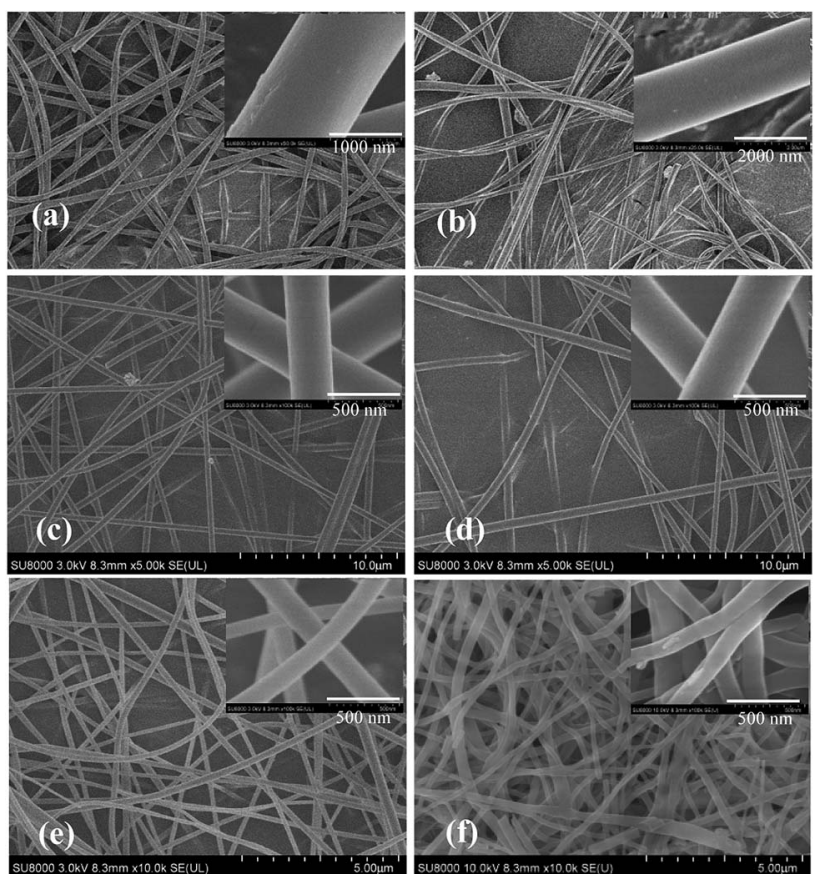

Fig. 3 SEM images of different mass fraction with poly(AN-MA- $\beta-C D$ ) in DMF: (a) $36 \%$, (b) $33 \%$, (c) $30 \%$, (d) $25 \%$, (e) $20 \%$, and (f) catalyst bind to poly(AN-MA- $\beta-C D)$.

reports, benzene and adamantane can be recovered by $\mathrm{CD}$ via host-guest interaction. ${ }^{12}$ The reaction of cyclohexanone with $m$-nitrobenzaldehyde was selected as a model for assessing the recyclability of catalyst because $m$-nitrobenzaldehyde with steric hindrance did not easily turn into the $\beta$-CD cavity and adamantine-modified catalyst was recovered by fibrous membrane via host-guest interaction from the reaction medium. The recycling process of catalyst is shown in Scheme 2. The adsorption rate of catalyst in mixture of $\mathrm{MeOH} / \mathrm{H}_{2} \mathrm{O}$ $98.5 \%$, and the separation rate from the fibrous membrane was $97.7 \%$. Therefore, the total recovery rate was $96.2 \%$. The relevant results about recyclability of catalyst are summarized in Table 4 . In the first three recycles, conversions were above 95\% with excellent diastereoselectivities and enantioselectivities under the same reaction time. Prolonging the reaction time could also provide good yields with desirable diastereoselectivities from the third cycle. In the sixth run, the yield

Table 4 Recycling experiments ${ }^{a}$

\begin{tabular}{lllll}
\hline Entry & Time $(\mathrm{h})$ & Yield $^{b}(\%)$ & $\mathrm{dr}^{c}($ syn/anti $)$ & $e e^{c}(\%)$ \\
\hline 1 & 48 & 97 & $99: 1$ & 98 \\
2 & 48 & 98 & $>99: 1$ & 99 \\
3 & 48 & 95 & $98: 2$ & 97 \\
4 & 60 & 95 & $99: 1$ & 97 \\
5 & 60 & 90 & $98: 2$ & 96 \\
6 & 72 & 92 & $94: 6$ & 92
\end{tabular}

${ }^{a}$ Reaction conditions: $m$-nitrobenzaldehyde $(0.5 \mathrm{mmol})$, cyclohexanone (10 equiv.), catalyst $1 \mathrm{~d}(0.05 \mathrm{mmol}, 10 \mathrm{~mol} \%)$ only being added at first run, solvent $(1.0 \mathrm{~mL}), 0{ }^{\circ} \mathrm{C}$. ${ }^{b}$ Combined yields of isolated. ${ }^{c}$ Determined by HPLC with a chiral AD-H column. 
was $92 \%$ with ee value of $92 \%$. As shown in Table 4 , the catalyst can also be reused for up to five times without showing significant change in diastereoselectivity and enantioselectivity.

\section{Conclusions}

In summary, organocatalysts based on L-proline or trans-4-hydroxyL-proline with double-H potential were synthesized. Catalyst 1d (10 mol\%) demonstrated very efficient performance for catalyzing direct aldol reactions. The use of brine as solvent afforded aldol products in excellent yields (up to 98\% yield) with high diastereoselectivity (>99: 1) and enantioselectivity (>99\%). A nanofibrous film of $20 \%$ poly(AN-MA- $\beta$-CD) was formed by electrospinning and characterized by FTIR and SEM analyses. After each run, the catalyst adsorbed on the film via host-guest interaction in the reaction system and then separated from the film using ultrasound. The total recovery rate of the catalyst was $96.2 \%$, and the catalyst could be reused for up to five times without exhibiting significant change in diastereoselectivity and enantioselectivity.

\section{Experimental}

\section{General procedure}

All chemicals were used as received unless otherwise noted. All reagents were purchased from J\&K or Sigma-Aldrich Chemical Co. and were used without any further purification. Solvents were dried according to standard procedures. Reactions were monitored by thin-layer chromatography (TLC) carried out on silica gel 60F254 plates. Flash column chromatography was performed using silica gel (200-300 mesh, Qingdao Haiyang Chemical Co.). ${ }^{1} \mathrm{H}$ and ${ }^{13} \mathrm{C}$ NMR spectra were taken on a Bruker AV-400 MHz spectrometer. All chemical shifts $(\delta)$ were given in ppm. Chemical shifts ( $\delta \mathrm{ppm})$ are relative to the resonance of the deuterated solvent as the internal standard $\left(\mathrm{CDCl}_{3}\right.$, $\delta 7.26 \mathrm{ppm}$ for proton NMR, $\delta 77.36 \mathrm{ppm}$ for carbon NMR; DMSO-d6, $\delta 2.54$ ppm for proton NMR, $\delta 40.45$ ppm for carbon NMR). Data are presented as follows: chemical shift, integration, multiplicity ( $\mathrm{br}=$ broad, $\mathrm{s}=$ singlet, $\mathrm{d}=$ doublet, $\mathrm{t}=$ triplet, $\mathrm{q}=$ quartet, $\mathrm{m}=$ multiplet) and coupling constant in hertz (Hz). Mass spectra were recorded on the Bruker Agilent 1290 MicrOTOF Q II. Melting points were measured on a melting point apparatus and were uncorrected. The ee values determination was carried out using chiral HPLC (Waters) with Chiracel AD-H column, Chiracel OD-H column and Chiracel AS$\mathrm{H}$ column. Optical rotations were measured on a Shanghai Shen Guang SGW-2 Polarimeter at $\lambda=589 \mathrm{~nm}$. Optical rotations are reported as follows: $[\alpha]_{\mathrm{D}}^{25}(c=\mathrm{g} / 100 \mathrm{~mL}$, solvent). IR spectra were recorded on a Bruker Vector-22 spectrometer. UV-Vis spectra were recorded on a Hitachi U-3010 UV-Vis spectrophotometer. High voltage power (0-50 kV) DW-P503-1AC (Tianjin, China), and scanning electron microscope (SEM) were also used.

\section{Synthesis of catalysts: the catalysts were prepared according to previous works ${ }^{3,4}$}

To a flask containing $o$-phenylenediamine $(1.08 \mathrm{~g}, 10.0 \mathrm{mmol}$, 1.0 equiv.) dissolved in dry $\mathrm{CH}_{2} \mathrm{Cl}_{2}(30 \mathrm{~mL})$ at $0{ }^{\circ} \mathrm{C}$, and a solution of acid (10.0 mmol, 1.0 equiv.), DMAP (0.98 g, $8.0 \mathrm{mmol}, 0.8$ equiv.), and EDCI ( $2.30 \mathrm{~g}, 12.0 \mathrm{mmol}, 1.2$ equiv.) in $\mathrm{CH}_{2} \mathrm{Cl}_{2}(20 \mathrm{~mL})$ was added into solvent after 5 min with vigorous stirring. The resulting reaction mixture was stirred at room temperature for overnight. The solvent was evaporated. The aqueous layer was extracted with ethyl acetate. The combined organic layer was dried $\left(\mathrm{MgSO}_{4}\right)$ and then evaporated under reduced pressure to the crude products which was further purified via silica gel column chromatography (EtOAc : PE $=1: 5$ ) to afford compound.

Boc-L-hydroxyproline or Boc-L-proline ( $6.0 \mathrm{mmol}, 1.2$ equiv.) was dissolved in dry $\mathrm{CH}_{2} \mathrm{Cl}_{2}(20 \mathrm{~mL})$ and cooled to $0{ }^{\circ} \mathrm{C}$. And DMAP (0.49 g, $4.0 \mathrm{mmol}, 0.8$ equiv.) and EDCI (1.15 g, $6.0 \mathrm{mmol}$, 1.2 equiv.) were added. A solution of phenylamine 1 (1.06 g, 5.0 $\mathrm{mmol})$ in dry $\mathrm{CH}_{2} \mathrm{Cl}_{2}(20 \mathrm{~mL})$ was then added dropwise after $15 \mathrm{~min}$ with vigorous stirring. The resulting reaction mixture was stirred at room temperature and monitored by TLC. After completion of the reaction, the mixture was partitioned between EtOAc and water. The organic layer was washed with saturated brine. The combined organic layer was dried $\left(\mathrm{MgSO}_{4}\right)$ and then evaporated under reduced pressure to crude product.

The crude product was then dissolved in $\mathrm{CH}_{2} \mathrm{Cl}_{2}(20 \mathrm{~mL})$ and cooled to $0{ }^{\circ} \mathrm{C}$. Trifluoroacetic acid (10.0 equiv.) was added dropwise to mixture solution and further stirred at room temperature for another $4 \mathrm{~h}$. After the reaction was completed, mixture was quenched with saturated $\mathrm{NaHCO}_{3}$ aqua. The aqueous layer was extracted with ethyl acetate, and the organic layer was successively washed with water and another portion of saturated brine, dried $\left(\mathrm{MgSO}_{4}\right)$ and evaporated under reduced pressure. The oily residue was purified by silica gel chromatography (ethyl acetate/methanol $\left.\left(3 \% \mathrm{Et}_{3} \mathrm{~N}\right)=10: 1\right)$ to give compound.

(S)-N-(2-Benzamidophenyl)-4-hydroxyprolinamide (1a). White solid (1.12 g, yield 69\%). Mp $=164-165{ }^{\circ} \mathrm{C},[\alpha]_{\mathrm{D}}^{25}=+11.6$ $\left(c=0.5, \mathrm{CH}_{3} \mathrm{OH}\right) .{ }^{1} \mathrm{H}$ NMR $(400 \mathrm{MHz}, \mathrm{DMSO}) \delta=10.22(\mathrm{~d}, J=$ $15.4 \mathrm{~Hz}, 1 \mathrm{H}), 8.05$ (dd, $J=12.8,7.9 \mathrm{~Hz}, 2 \mathrm{H}), 7.65$ (t, $J=7.2 \mathrm{~Hz}$, $1 \mathrm{H}), 7.59$ (t, $J=7.4 \mathrm{~Hz}, 1 \mathrm{H}), 7.40(\mathrm{~d}, J=7.8 \mathrm{~Hz}, 1 \mathrm{H}), 7.32(\mathrm{t}, J=$ $7.7 \mathrm{~Hz}, 1 \mathrm{H}), 7.19(\mathrm{t}, J=7.6 \mathrm{~Hz}, 1 \mathrm{H}), 4.70(\mathrm{~d}, J=2.6 \mathrm{~Hz}, 1 \mathrm{H}), 4.15$ $(\mathrm{s}, 1 \mathrm{H}), 3.91(\mathrm{t}, J=8.2 \mathrm{~Hz}, 1 \mathrm{H}), 3.40(\mathrm{~s}, 1 \mathrm{H}), 2.64(\mathrm{dt}, J=11.5$, $7.4 \mathrm{~Hz}, 1 \mathrm{H}), 2.10-2.00(\mathrm{~m}, 1 \mathrm{H}), 1.83-1.73(\mathrm{~m}, 1 \mathrm{H}) \mathrm{ppm} .{ }^{13} \mathrm{C} \mathrm{NMR}$ (101 MHz, DMSO) $\delta=174.34,166.77,134.99,134.46,132.72$, 129.41, 129.20, 128.59, 128.15, 127.59, 124.83, 122.56, 72.33, $60.90,55.65,40.54$ ppm. HRMS (ESI): calcd for $\mathrm{C}_{18} \mathrm{H}_{20} \mathrm{~N}_{3} \mathrm{O}_{3}{ }^{+}[\mathrm{M}$ $+\mathrm{H}]^{+}$326.1499; found 326.1500.

(S)-N-(2-Benzamidophenyl)prolinamide (1b). White solid $(0.93 \mathrm{~g}$, yield $60 \%) . \mathrm{Mp}=159-160{ }^{\circ} \mathrm{C},[\alpha]_{\mathrm{D}}^{25}=-6.0(c=0.5$, $\mathrm{CH}_{3} \mathrm{OH}$ ). ${ }^{1} \mathrm{H}$ NMR (400 MHz, DMSO): $\delta=10.24$ (d, $J=13.2 \mathrm{~Hz}$, $1 \mathrm{H}), 8.07$ (dd, $J=16.6,7.8 \mathrm{~Hz}, 2 \mathrm{H}), 7.62(\mathrm{dt}, J=14.7,7.1 \mathrm{~Hz}, 2 \mathrm{H})$, $7.43-7.28(\mathrm{~m}, 1 \mathrm{H}), 7.19(\mathrm{t}, J=7.5 \mathrm{~Hz}, 1 \mathrm{H}), 3.73(\mathrm{dd}, J=9.1$, $4.6 \mathrm{~Hz}, 1 \mathrm{H}), 3.20(\mathrm{~s}, 1 \mathrm{H}), 2.78(\mathrm{dd}, J=11.7,4.7 \mathrm{~Hz}, 1 \mathrm{H}), 2.65-$ $2.56(\mathrm{~m}, 1 \mathrm{H}), 2.09-1.96(\mathrm{~m}, 1 \mathrm{H}), 1.80(\mathrm{dd}, J=12.0,5.6 \mathrm{~Hz}, 1 \mathrm{H})$, 1.57 (dt, $J=13.3,6.6 \mathrm{~Hz}, 1 \mathrm{H}) \mathrm{ppm} .{ }^{13} \mathrm{C}$ NMR (101 MHz, DMSO): $\delta=174.50,166.73$ (s), 134.93, 134.62, 132.73, 129.42, 129.14, 128.56, 128.18, 127.63, 61.58, 47.45, 31.41, 26.75 ppm. HRMS (ESI): calcd for $\mathrm{C}_{18} \mathrm{H}_{20} \mathrm{~N}_{3} \mathrm{O}_{2}{ }^{+}[\mathrm{M}+\mathrm{H}]^{+} 310.1550$; found 310.1550.

$(S)-N$-(2-(Adamantane-1-carboxamidophenyl))-4-

hydroxyprolinam-ide (1c). White solid (1.36 g, yield 71\%). Mp = 
209-210 ${ }^{\circ} \mathrm{C},[\alpha]_{\mathrm{D}}^{25}=-11.2\left(c=0.5, \mathrm{CH}_{3} \mathrm{OH}\right) .{ }^{1} \mathrm{H} \mathrm{NMR}(400 \mathrm{MHz}$, DMSO): $\delta=10.02(\mathrm{~s}, 1 \mathrm{H}), 9.11(\mathrm{~s}, 1 \mathrm{H}), 8.01(\mathrm{~d}, J=8.2 \mathrm{~Hz}, 1 \mathrm{H})$, 7.24 (dd, $J=12.1,4.5 \mathrm{~Hz}, 3 \mathrm{H}), 7.15-7.09$ (m, 1H), 4.81 (s, 1H), $4.25(\mathrm{~s}, 1 \mathrm{H}), 3.95(\mathrm{t}, J=8.3 \mathrm{~Hz}, 1 \mathrm{H}), 3.04(\mathrm{q}, J=7.2 \mathrm{~Hz}, 2 \mathrm{H}), 2.91-$ $2.81(\mathrm{~m}, 3 \mathrm{H}), 2.08$ (d, $J=9.7 \mathrm{~Hz}, 4 \mathrm{H}), 2.02-1.92(\mathrm{~m}, 8 \mathrm{H}), 1.80-$ $1.72(\mathrm{~m}, 8 \mathrm{H}), 1.18(\mathrm{t}, J=7.3 \mathrm{~Hz}, 3 \mathrm{H}) .{ }^{13} \mathrm{C}$ NMR $(101 \mathrm{MHz}$, DMSO): $\delta=177.40,174.08,134.18,129.54,128.15,127.07$, 124.67, 122.26, 72.25, 60.88, 55.87, 46.61, 41.46, 39.57, 37.06, 28.64 ppm. HRMS (ESI): calcd for $\mathrm{C}_{22} \mathrm{H}_{30} \mathrm{~N}_{3} \mathrm{O}_{3}{ }^{+}[\mathrm{M}+\mathrm{H}]^{+}$ 384.2282; found 384.2282.

(S)-N-(2-(Adamantane-1-carboxamidophenyl))prolinamide (1d). White solid $(1.23 \mathrm{~g}$, yield $67 \%) . \mathrm{Mp}=213-214^{\circ} \mathrm{C},[\alpha]_{\mathrm{D}}^{25}=$ $-24.4\left(c=0.5, \mathrm{CH}_{3} \mathrm{OH}\right) .{ }^{1} \mathrm{H}$ NMR (400 MHz, DMSO): $\delta=10.08$ (s, 1H), $9.01(\mathrm{~s}, 1 \mathrm{H}), 7.82(\mathrm{~d}, J=7.9 \mathrm{~Hz}, 1 \mathrm{H}), 7.36-7.32(\mathrm{~m}, 1 \mathrm{H})$, $7.27-7.22(\mathrm{~m}, 1 \mathrm{H}), 7.18$ (dd, $J=10.8,4.4 \mathrm{~Hz}, 1 \mathrm{H}), 4.05$ (dd, $J=$ 8.7, $6.0 \mathrm{~Hz}, 1 \mathrm{H}), 3.17-2.97(\mathrm{~m}, 3 \mathrm{H}), 2.22(\mathrm{dt}, J=15.8,8.0 \mathrm{~Hz}, 1 \mathrm{H})$, $2.06(\mathrm{~s}, 3 \mathrm{H}), 1.96(\mathrm{~d}, J=7.1 \mathrm{~Hz}, 6 \mathrm{H}), 1.84-1.68(\mathrm{~m}, 10 \mathrm{H}), 1.21(\mathrm{t}, J$ $=7.3 \mathrm{~Hz}, 1 \mathrm{H}) \mathrm{ppm} .{ }^{13} \mathrm{C}$ NMR (101 MHz, DMSO): $\delta=177.19$, 171.96, 132.98, 130.61, 127.78, 126.74, 125.49, 123.75, 61.15, 47.35, 41.52, 39.53, 37.02, 31.04, 28.61, 25.95 ppm. HRMS (ESI): calcd for $\mathrm{C}_{22} \mathrm{H}_{30} \mathrm{~N}_{3} \mathrm{O}_{2}{ }^{+}[\mathrm{M}+\mathrm{H}]^{+}$368.2333; found 368.2333.

\section{The preparation of poly(AN-MA- $\beta-\mathrm{CD})$}

The poly(AN-MA- $\beta$-CD) was prepared according to previous works in our group. ${ }^{19} \mathrm{AN}(30 \mathrm{~g}, 0.57 \mathrm{~mol})$ and MA $(7.21 \mathrm{~g}, 0.1$ mol) were dissolved in dry DMF (149 g) at $0{ }^{\circ} \mathrm{C}$ for vigorous string $15 \mathrm{~min}$. And then PVP (0.037 g) and AIBN (0.372 g) was added into solvent. The resulting reaction mixture was stirred at $70{ }^{\circ} \mathrm{C}$ for overnight. After reaction, a large of distilled water was added and precipitate was observed. The solid was washed with distilled water another three times and dried at vacuum oven for overnight to give the poly(AN-MA) $18.23 \mathrm{~g}$ (yield: 49\%).

The polymer $(5 \mathrm{~g})$ dissolved in dry DMF $(80 \mathrm{~mL})$ at $0{ }^{\circ} \mathrm{C}$, and then DMAP (19.17 g, $0.1 \mathrm{~mol})$ and EDCI $(1.22 \mathrm{~g}, 0.01 \mathrm{~mol})$ was added into solvent after vigorous stirring with $5 \mathrm{~min}$. $\beta$-CD in dry DMF $(500 \mathrm{~mL})$ was added dropwise under $0{ }^{\circ} \mathrm{C}$. The resulting reaction mixture was stirred at room temperature for overnight. The solvent was evaporated after complete reaction. A large of distilled water was added and solid was precipitated. The solid was washed with distilled water another three times and dried at vacuum oven for overnight to give poly(AN-MA- $\beta$ CD) $11.03 \mathrm{~g}$.

\section{The preparation of fibrous film}

The poly(AN-MA- $\beta$-CD) dissolved in DMF was changed into fibrous membrane by electrospinning, and the preparation flowchart of fibrous membrane was shown in Scheme $2 .^{20}$ The electrospinning solution was moved into the $5.0 \mathrm{~mL}$ injector with a stainless-steel needle of inner diameter about $1 \mathrm{~mm}$, and the distance from the needle to the receiving plate was adjusted to $15-18 \mathrm{~cm}$. Fibrous membrane was collected on aluminium foil with a liquid flow rate of $1.0 \mathrm{~mL} \mathrm{~h}^{-1}$ and a voltage of $15.4 \mathrm{kV}$. After $4 \mathrm{~h}$ of continuous electrospinning, aluminium foil was placed into the oven at $40{ }^{\circ} \mathrm{C}$ for $6 \mathrm{~h}$.

\section{General procedure for asymmetric aldol reaction}

The following procedure for the reaction of cyclohexanone with $p$-nitrobenzaldehyde in brine using catalyst 1d was representative. To a mixture of catalyst $1 \mathrm{~d}(18.4 \mathrm{mg}, 0.05 \mathrm{mmol})$ and $p$ nitrobenzaldehyde ( $75 \mathrm{mg}, 0.5 \mathrm{mmol})$ in brine $(1 \mathrm{~mL})$ was added under air in a closed system. The reaction mixture was stirred at $0{ }^{\circ} \mathrm{C}$ for $15 \mathrm{~min}$, and then cyclohexanone (10 equiv.) was added. After the reaction mixtures were stirred for $48 \mathrm{~h}$, the mixtures were quenched with $2 \mathrm{M}$ ammonium chloride solution and extracted with ethyl acetate. The organic layer was dried over $\mathrm{Na}_{2} \mathrm{SO}_{4}$, filtered, and concentrated to give pure aldol product after flash column chromatography (silica gel, petroleum ether/ ethyl acetate $=3 / 1$ ). The product was a light yellow or white solid. The absolute configuration of aldol products was extrapolated by comparison of the HPLC-data with known literatures. ${ }^{15,21}$

(2S,1'R)-2-(Hydroxy-(4-nitrophenyl)methyl)cyclohexan-1-one (4a). Reaction time: 48 h; yield: 98\%; light yellow solid. Enantiomeric excess: $96 \%$, determined by HPLC with a Chiral-pack AD-H column (90:10 hexane : 2-propanol), $1 \mathrm{~mL} \mathrm{~min}^{-1}$; $254 \mathrm{~nm}, 25{ }^{\circ} \mathrm{C} ; t_{\mathrm{R}}$ (major) $=31.2 \mathrm{~min}, t_{\mathrm{R}}$ (minor) $=23.7 \mathrm{~min} .{ }^{1} \mathrm{H}$ NMR (400 MHz, DMSO): $\delta=8.20(\mathrm{t}, J=7.6 \mathrm{~Hz}, 2 \mathrm{H}), 7.63(\mathrm{t}, J=$ $8.9 \mathrm{~Hz}, 2 \mathrm{H}), 5.54$ (d, $J=27.0 \mathrm{~Hz}, 1 \mathrm{H}), 5.12(\mathrm{~d}, J=7.0 \mathrm{~Hz}, 1 \mathrm{H})$, 2.71 (ddd, $J=20.8,10.9,5.5 \mathrm{~Hz}, 1 \mathrm{H}), 2.37$ (s, 2H), 1.58 (s, 5H), $1.20(\mathrm{td}, J=19.3,9.1 \mathrm{~Hz}, 1 \mathrm{H}) \mathrm{ppm} .{ }^{13} \mathrm{C} \mathrm{NMR}$ (101 MHz, DMSO): $\delta=211.39,153.81,147.23,128.81,128.10,123.72$, 69.31, 57.15, 42.25, 30.20, 28.12, $24.31 \mathrm{ppm}$.

(2S,1'R)-2-(Hydroxy-(3-nitrophenyl)methyl)cyclohexan-1-one (4b). Reaction time: 48 h; yield: 97\%; light yellow solid. Enantiomeric excess: $98 \%$, determined by HPLC with a Chiralpack AD-H column (95: 5 hexane : 2-propanol), $1 \mathrm{~mL} \mathrm{~min}^{-1} ; 254 \mathrm{~nm}$, $25{ }^{\circ} \mathrm{C} ; t_{\mathrm{R}}$ (major) $=34.8 \mathrm{~min}, t_{\mathrm{R}}$ (minor) $=44.5 \mathrm{~min} .{ }^{1} \mathrm{H} \mathrm{NMR}$ (400 MHz, DMSO): $\delta=8.17(\mathrm{~s}, 1 \mathrm{H}), 8.08(\mathrm{~d}, J=8.3 \mathrm{~Hz}, 1 \mathrm{H}), 7.76$ $(\mathrm{d}, J=7.1 \mathrm{~Hz}, 1 \mathrm{H}), 7.58(\mathrm{t}, J=7.9 \mathrm{~Hz}, 1 \mathrm{H}), 5.52(\mathrm{~d}, J=4.4 \mathrm{~Hz}$, $1 \mathrm{H}), 5.13-5.03(\mathrm{~m}, 1 \mathrm{H}), 2.70(\mathrm{~d}, J=4.7 \mathrm{~Hz}, 1 \mathrm{H}), 2.30(\mathrm{~s}, 2 \mathrm{H}), 1.78$ (d, $J=25.2 \mathrm{~Hz}, 2 \mathrm{H}), 1.55$ (s, 3H), 1.15 (d, $J=11.8 \mathrm{~Hz}, 1 \mathrm{H}) \mathrm{ppm}$. ${ }^{13} \mathrm{C}$ NMR (101 MHz, DMSO): $\delta=211.75,148.51,146.96,134.61$, $130.25,122.83,122.35,71.20,58.14,42.21,30.31,28.30$, $24.15 \mathrm{ppm}$.

(2S,1'R)-2-(Hydroxy-(2-nitrophenyl)methyl)cyclohexan-1-one (4c). Reaction time: 48 h; yield: 97\%; light yellow solid. Enantiomeric excess: $97 \%$, determined by HPLC with a Chiralpack AD-H column (95: 5 hexane : 2-propanol), $1 \mathrm{~mL} \mathrm{~min}^{-1} ; 254 \mathrm{~nm}$, $25{ }^{\circ} \mathrm{C} ; t_{\mathrm{R}}$ (major) $=16.8 \mathrm{~min}, t_{\mathrm{R}}($ minor $)=19.1 \mathrm{~min} .{ }^{1} \mathrm{H} \mathrm{NMR}$ (400 MHz, DMSO): $\delta=7.81(\mathrm{~d}, J=8.1 \mathrm{~Hz}, 1 \mathrm{H}), 7.69(\mathrm{~d}, J=$ $4.2 \mathrm{~Hz}, 2 \mathrm{H}), 7.50(\mathrm{dt}, J=8.3,4.3 \mathrm{~Hz}, 1 \mathrm{H}), 5.76(\mathrm{~s}, 1 \mathrm{H}), 5.60(\mathrm{~d}, J=$ $4.5 \mathrm{~Hz}, 1 \mathrm{H}), 2.89-2.69(\mathrm{~m}, 1 \mathrm{H}), 2.46-2.35(\mathrm{~m}, 1 \mathrm{H}), 2.28(\mathrm{dd}, J=$ 12.8, $4.4 \mathrm{~Hz}, 1 \mathrm{H}), 1.90$ (s, 1H), 1.75-1.66 (m, 1H), 1.63-1.49 (m, $2 \mathrm{H}), 1.44(\mathrm{~d}, J=13.2 \mathrm{~Hz}, 1 \mathrm{H}), 1.37-1.21(\mathrm{~m}, 1 \mathrm{H}) \mathrm{ppm} .{ }^{13} \mathrm{C} \mathrm{NMR}$ (101 MHz, DMSO): $\delta=211.13,149.60,138.36,133.34,130.33$, 129.04, 124.09, 67.28, 57.85, 42.59, 31.28, 28.57, 24.68 ppm.

(2S,1'R)-2-(Hydroxy-(4-cyanophenyl)methyl)cyclohexan-1one (4d). Reaction time: 48 h; yield: 93\%; white solid. Enantiomeric excess: $97 \%$, determined by HPLC with a Chiralpack OD-H column (95:5 hexane : 2-propanol), $1 \mathrm{~mL} \mathrm{~min}^{-1}$; $220 \mathrm{~nm}, 25{ }^{\circ} \mathrm{C} ; t_{\mathrm{R}}$ (major) $=25.7 \mathrm{~min}, t_{\mathrm{R}}($ minor $)=37.3 \mathrm{~min} .{ }^{1} \mathrm{H}$ 
NMR (400 MHz, DMSO): $\delta=7.78(\mathrm{~d}, J=8.0 \mathrm{~Hz}, 2 \mathrm{H}), 7.53(\mathrm{~d}, J=$ $8.0 \mathrm{~Hz}, 2 \mathrm{H}), 5.46$ (s, 1H), 5.03 (d, $J=7.2 \mathrm{~Hz}, 1 \mathrm{H}), 2.67$ (dd, $J=$ 13.2, 8.9 Hz, 1H), $2.34(\mathrm{t}, J=6.2 \mathrm{~Hz}, 2 \mathrm{H}), 1.92-1.69(\mathrm{~m}, 2 \mathrm{H})$, 1.68-1.45 (m, 3H), 1.15 (dd, $J=20.6,10.6 \mathrm{~Hz}, 1 \mathrm{H}) \mathrm{ppm} .{ }^{13} \mathrm{C}$ NMR (101 MHz, DMSO): $\delta=211.70,150.31,132.75,128.79$, 119.86, 110.61, 71.62, 58.18, 42.13, 30.44, 28.37, 24.05 ppm.

(2S,1'R)-2-(Hydroxy-(3-cyanophenyl)methyl)cyclohexan-1one (4e). Reaction time: 48 h; yield: 90\%; white solid. Enantiomeric excess: 97\%, determined by HPLC with a Chiralpack OD-

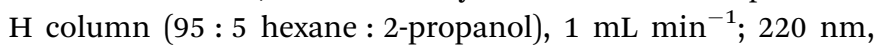
$25{ }^{\circ} \mathrm{C} ; t_{\mathrm{R}}$ (major) $=24.8 \mathrm{~min}, t_{\mathrm{R}}($ minor $)=29.3 \mathrm{~min} .{ }^{1} \mathrm{H} \mathrm{NMR}$ (400 MHz, DMSO): $\delta=7.76(\mathrm{~s}, 1 \mathrm{H}), 7.70(\mathrm{dd}, J=12.9,7.8 \mathrm{~Hz}$, $2 \mathrm{H}), 7.54(\mathrm{t}, J=7.7 \mathrm{~Hz}, 1 \mathrm{H}), 5.43(\mathrm{~s}, 1 \mathrm{H}), 5.00(\mathrm{~d}, J=7.2 \mathrm{~Hz}, 1 \mathrm{H})$, $2.70(\mathrm{t}, J=10.9 \mathrm{~Hz}, 1 \mathrm{H}), 2.33(\mathrm{~d}, J=5.8 \mathrm{~Hz}, 2 \mathrm{H}), 1.93-1.69(\mathrm{~m}$, 2H), 1.69-1.43 (m, 3H), 1.22-1.08 (m, 1H) ppm. ${ }^{13} \mathrm{C}$ NMR (101 MHz, DMSO): $\delta=211.40,145.74,132.32,131.27,130.94,129.61$, 119.44, 111.30, 70.93, 57.63, 41.72, 30.03, 27.95, $23.62 \mathrm{ppm}$.

(2S,1'R)-2-(Hydroxy-(2-cyanophenyl)methyl)cyclohexan-1-

one (4f). Reaction time: 48 h; yield: 91\%; white solid. Enantiomeric excess: $97 \%$, determined by HPLC with a Chiralpack OD$\mathrm{H}$ column (95: 5 hexane : 2-propanol), $1 \mathrm{~mL} \min ^{-1} ; 220 \mathrm{~nm}$, $25{ }^{\circ} \mathrm{C} ; t_{\mathrm{R}}$ (major) $=16.3 \mathrm{~min}, t_{\mathrm{R}}$ (minor) $=18.6 \mathrm{~min} .{ }^{1} \mathrm{H} \mathrm{NMR}$ (400 MHz, DMSO): $\delta=7.78(\mathrm{~d}, J=7.7 \mathrm{~Hz}, 1 \mathrm{H}), 7.72(\mathrm{t}, J=7.6 \mathrm{~Hz}$, $1 \mathrm{H}), 7.63$ (d, $J=7.9 \mathrm{~Hz}, 1 \mathrm{H}), 7.47$ (t, $J=7.5 \mathrm{~Hz}, 1 \mathrm{H}), 5.67$ (d, $J=$ $4.1 \mathrm{~Hz}, 1 \mathrm{H}), 5.17(\mathrm{dd}, J=8.8,4.0 \mathrm{~Hz}, 1 \mathrm{H}), 2.76(\mathrm{td}, J=9.5$, $5.4 \mathrm{~Hz}, 1 \mathrm{H}), 2.38(\mathrm{ddd}, J=17.6,11.4,6.3 \mathrm{~Hz}, 2 \mathrm{H}), 1.96-1.81(\mathrm{~m}$, $1 \mathrm{H}), 1.69$ (ddd, $J=19.2,18.5,13.2 \mathrm{~Hz}, 2 \mathrm{H}), 1.56$ (dd, $J=16.1$, $6.6 \mathrm{~Hz}, 1 \mathrm{H}), 1.40-1.30(\mathrm{~m}, 1 \mathrm{H}), 1.23(\mathrm{dd}, J=19.8,10.0 \mathrm{~Hz}$, $1 \mathrm{H}) \mathrm{ppm} .{ }^{13} \mathrm{C}$ NMR (101 MHz, DMSO): $\delta=211.41,148.19$, $134.31,133.40,129.08,129.03$, 118.77, 111.23, 70.52, 58.02, 42.48, 31.27, 28.93, $24.42 \mathrm{ppm}$.

(2S,1'R)-2-(Hydroxy-(4-trifluoromethylphenyl)methyl)cyclohexan-1-one (4g). Reaction time: 48 h; yield: 94\%; white solid. Enantiomeric excess: 97\%, determined by HPLC with a Chiralpack AD-H column (90: 10 hexane : 2-propanol), $1 \mathrm{~mL} \mathrm{~min}^{-1}$; $220 \mathrm{~nm}, 25{ }^{\circ} \mathrm{C} ; t_{\mathrm{R}}$ (major) $=12.8 \mathrm{~min}, t_{\mathrm{R}}$ (minor) $=10.4 \mathrm{~min} .{ }^{1} \mathrm{H}$ NMR (400 MHz, DMSO): $\delta=7.68(\mathrm{~d}, J=8.1 \mathrm{~Hz}, 2 \mathrm{H}), 7.56(\mathrm{~d}, J=$ $8.1 \mathrm{~Hz}, 2 \mathrm{H}), 5.42(\mathrm{~d}, J=4.5 \mathrm{~Hz}, 1 \mathrm{H}), 5.05(\mathrm{dd}, J=7.2,4.6 \mathrm{~Hz}$, $1 \mathrm{H}), 2.72-2.64(\mathrm{~m}, 1 \mathrm{H}), 2.36(\mathrm{t}, J=6.5 \mathrm{~Hz}, 2 \mathrm{H}), 1.91-1.70(\mathrm{~m}$, $2 \mathrm{H}), 1.70-1.47(\mathrm{~m}, 3 \mathrm{H}), 1.16$ (ddd, $J=13.2,10.4,6.9 \mathrm{~Hz}$, 1H) ppm. ${ }^{13} \mathrm{C}$ NMR (101 MHz, DMSO): $\delta=211.67,149.11$, 128.49 , 128.39, 125.45, 71.44, 58.12, 41.89, 30.28, 28.22, $23.80 \mathrm{ppm}$.

(2S,1'R)-2-(Hydroxy-(2,4-dichlorophenyl)methyl)cyclohexan1-one (4h). Reaction time: 48 h; yield: 90\%; white solid. Enantiomeric excess: $98 \%$, determined by HPLC with a Chiralpack OD-H column (95:5 hexane : 2-propanol), $1 \mathrm{~mL} \mathrm{~min}^{-1}$; $220 \mathrm{~nm}, 25{ }^{\circ} \mathrm{C} ; t_{\mathrm{R}}$ (major) $=9.5 \mathrm{~min}, t_{\mathrm{R}}($ minor $)=11.7 \mathrm{~min} .{ }^{1} \mathrm{H}$ NMR (400 MHz, DMSO): $\delta=7.54$ (d, $J=8.4 \mathrm{~Hz}, 2 \mathrm{H}), 7.44$ (dd, $J$ $=8.5,1.4 \mathrm{~Hz}, 1 \mathrm{H}), 5.48(\mathrm{~d}, J=4.6 \mathrm{~Hz}, 1 \mathrm{H}), 5.25(\mathrm{dd}, J=8.4$, $4.6 \mathrm{~Hz}, 1 \mathrm{H}), 2.71-2.61(\mathrm{~m}, 1 \mathrm{H}), 2.42-2.30(\mathrm{~m}, 2 \mathrm{H}), 1.92-1.32(\mathrm{~m}$, $6 \mathrm{H})$ ppm. ${ }^{13} \mathrm{C}$ NMR (101 MHz, DMSO): $\delta=211.07,132.91$, 132.65, 130.93, 128.52, 128.09, 67.89, 57.67, 42.13, 30.70, 28.37, $24.11 \mathrm{ppm}$.

(2S,1'R)-2-(Hydroxy-(4-chlorophenyl)methyl)cyclohexan-1one (4i). Reaction time: 48 h; yield: $57 \%$; white solid. Enantiomeric excess: $98 \%$, determined by HPLC with a Chiralpack OD-
$\mathrm{H}$ column (95: 5 hexane : 2-propanol), $1 \mathrm{~mL} \min ^{-1} ; 220 \mathrm{~nm}$, $25{ }^{\circ} \mathrm{C} ; t_{\mathrm{R}}$ (major) $=12.0 \mathrm{~min}, t_{\mathrm{R}}($ minor $)=16.3 \mathrm{~min} .{ }^{1} \mathrm{H} \mathrm{NMR}$ (400 MHz, DMSO): $\delta=7.41-7.31(\mathrm{~m}, 4 \mathrm{H}), 5.29(\mathrm{~d}, J=4.4 \mathrm{~Hz}$, $1 \mathrm{H}), 4.96(\mathrm{dd}, J=7.7,4.4 \mathrm{~Hz}, 1 \mathrm{H}), 2.61(\mathrm{td}, J=8.9,5.3 \mathrm{~Hz}, 1 \mathrm{H})$, 2.41-2.28 (m, 2H), 1.89-1.70 (m, 2H), 1.64 (ddd, $J=12.4,5.8$, $3.4 \mathrm{~Hz}, 1 \mathrm{H}), 1.57-1.45$ (m, 2H), 1.21-1.08 (m, 1H) ppm. ${ }^{13} \mathrm{C}$ NMR (101 MHz, DMSO): $\delta=212.13,143.47,132.40,129.67,128.76$, 71.58, 58.49, 41.99, 30.49, 28.50, 23.86 ppm.

(2S,1'R)-2-(Hydroxy-(3-chlorophenyl)methyl)cyclohexan-1one (4j). Reaction time: 48 h; yield: $54 \%$; white solid. Enantiomeric excess: $98 \%$, determined by HPLC with a Chiralpack AD$\mathrm{H}$ column (95: 5 hexane : 2-propanol), $1 \mathrm{~mL} \mathrm{~min}^{-1} ; 220 \mathrm{~nm}$, $25{ }^{\circ} \mathrm{C} ; t_{\mathrm{R}}$ (major) $=17.1 \mathrm{~min}, t_{\mathrm{R}}($ minor $)=15.1 \mathrm{~min} .{ }^{1} \mathrm{H} \mathrm{NMR}$ (400 MHz, DMSO): $\delta=7.37-7.23(\mathrm{~m}, 4 \mathrm{H}), 5.31(\mathrm{~d}, J=4.5 \mathrm{~Hz}$, $1 \mathrm{H}), 4.92(\mathrm{dd}, J=7.6,4.5 \mathrm{~Hz}, 1 \mathrm{H}), 2.69-2.55$ (m, 1H), 2.37-2.27 (m, 2H), 1.85-1.68 (m, 2H), 1.66-1.56 (m, 1H), 1.55-1.42 (m, 2H), 1.20-1.07 (m, 1H) ppm. ${ }^{13} \mathrm{C}$ NMR (101 MHz, DMSO): $\delta=$ 211.80, 146.95, 133.41, 130.47, 127.65, 127.39, 126.34, 71.45, $58.14,41.86,30.36,28.29,23.74 \mathrm{ppm}$.

(2S 1'R)-2-(Hydroxy-(2-chlorophenyl)methyl)cyclohexan-1one (4k). Reaction time: 48 h; yield: 59\%; white solid. Enantiomeric excess: $99 \%$, determined by HPLC with a Chiralpack OD-H column (95:5 hexane : 2-propanol), $1 \mathrm{~mL} \mathrm{~min}^{-1}$; $220 \mathrm{~nm}, 25{ }^{\circ} \mathrm{C} ; t_{\mathrm{R}}$ (major) $=9.7 \mathrm{~min}, t_{\mathrm{R}}$ (minor) $=6.0 \mathrm{~min} .{ }^{1} \mathrm{H}$ NMR (400 MHz, DMSO): $\delta=7.54(\mathrm{~d}, J=7.6 \mathrm{~Hz}, 1 \mathrm{H}), 7.37$ (t, $J=$ $8.7 \mathrm{~Hz}, 2 \mathrm{H}), 7.27$ (t, $J=7.6 \mathrm{~Hz}, 1 \mathrm{H}), 5.38(\mathrm{~d}, J=3.8 \mathrm{~Hz}, 1 \mathrm{H}), 5.32$ $(\mathrm{d}, J=8.7 \mathrm{~Hz}, 1 \mathrm{H}), 2.75-2.60(\mathrm{~m}, 1 \mathrm{H}), 2.37(\mathrm{t}, J=6.5 \mathrm{~Hz}, 2 \mathrm{H})$, $1.85(\mathrm{dd}, J=11.2,5.7 \mathrm{~Hz}, 1 \mathrm{H}), 1.71(\mathrm{dt}, J=12.3,9.9 \mathrm{~Hz}, 2 \mathrm{H}), 1.53$ $(\mathrm{dd}, J=9.0,3.6 \mathrm{~Hz}, 1 \mathrm{H}), 1.45-1.27$ (m, 2H) ppm. ${ }^{13} \mathrm{C}$ NMR (101 MHz, DMSO): $\delta=211.62,142.03,132.44,129.69,129.43,129.41$, 128.14, 68.42, 58.31, 42.30, 30.93, 28.73, 24.30 ppm.

(2S,1'R)-2-(Hydroxy-(4-bromophenyl)methyl)cyclohexan-1one (4l). Reaction time: 48 h; yield: $50 \%$; white solid. Enantiomeric excess: $99 \%$, determined by HPLC with a Chiralpack AD$\mathrm{H}$ column (90:10 hexane : 2-propanol), $1 \mathrm{~mL} \mathrm{~min}^{-1} ; 220 \mathrm{~nm}$, $25{ }^{\circ} \mathrm{C} ; t_{\mathrm{R}}$ (major) $=16.7 \mathrm{~min}, t_{\mathrm{R}}($ minor $)=14.4 \mathrm{~min} .{ }^{1} \mathrm{H} \mathrm{NMR}$ (400 MHz, DMSO): $\delta=7.47$ (d, $J=7.8 \mathrm{~Hz}, 2 \mathrm{H}), 7.26(\mathrm{~d}, J=$ $7.7 \mathrm{~Hz}, 2 \mathrm{H}), 5.24(\mathrm{~s}, 1 \mathrm{H}), 4.90$ (d, $J=7.7 \mathrm{~Hz}, 1 \mathrm{H}), 3.35(\mathrm{~s}, 1 \mathrm{H})$, 2.39-2.22 (m, 2H), 1.74 (dd, $J=31.9,5.4 \mathrm{~Hz}, 2 \mathrm{H}), 1.61(\mathrm{~s}, 1 \mathrm{H})$, $1.48(\mathrm{~d}, J=9.3 \mathrm{~Hz}, 2 \mathrm{H}), 1.12$ (dd, $J=12.1,6.9 \mathrm{~Hz}, 1 \mathrm{H}) \mathrm{ppm} .{ }^{13} \mathrm{C}$ NMR (101 MHz, DMSO): $\delta=211.90,143.70,131.47,129.85$, 120.73, 71.42, 58.24, 41.79, 30.28, 28.28, 23.67 ppm.

(2S,1'R)-2-(Hydroxy-(2-bromophenyl)methyl)cyclohexan-1one (4m). Reaction time: 48 h; yield: 55\%; white solid. Enantiomeric excess: $97 \%$, determined by HPLC with a Chiralpack

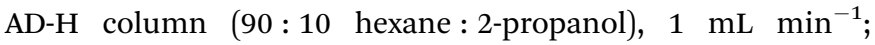
$220 \mathrm{~nm}, 25{ }^{\circ} \mathrm{C} ; t_{\mathrm{R}}$ (major) $=11.0 \mathrm{~min}, t_{\mathrm{R}}($ minor $)=12.8 \mathrm{~min} .{ }^{1} \mathrm{H}$ NMR (400 MHz, DMSO): $\delta=7.53$ (ddd, $J=11.6,7.9,1.3 \mathrm{~Hz}, 2 \mathrm{H}$ ), $7.40(\mathrm{dd}, J=11.0,3.9 \mathrm{~Hz}, 1 \mathrm{H}), 7.19(\mathrm{td}, J=8.0,1.7 \mathrm{~Hz}, 1 \mathrm{H}), 5.41$ (s, 1H), 5.27 (d, $J=8.7 \mathrm{~Hz}, 1 \mathrm{H}), 2.68(\mathrm{dd}, J=15.7,8.1 \mathrm{~Hz}, 1 \mathrm{H})$, 2.37 (dd, $J=10.6,5.4 \mathrm{~Hz}, 2 \mathrm{H}), 1.86$ (dd, $J=11.5,5.3 \mathrm{~Hz}, 1 \mathrm{H}$ ), 1.80-1.61 (m, 2H), 1.60-1.45 (m, 1H), 1.41-1.30 (m, 2H) ppm. ${ }^{13} \mathrm{C}$ NMR (101 MHz, DMSO): $\delta=211.74,143.84,132.88,130.14$, 129.98, 128.88, 123.37, 71.07, 58.58, 42.61, 31.29, 28.93, $24.65 \mathrm{ppm}$.

$\left(2 S, 1^{\prime} R\right)$-2-(Hydroxy-(4-fluorophenyl)methyl)cyclohexan-1one (4n). Reaction time: $48 \mathrm{~h}$; yield: 46\%; white solid. 
Enantiomeric excess: 95\%, determined by HPLC with a Chiralpack OD-H column (95 : 5 hexane : 2-propanol), $1 \mathrm{~mL} \mathrm{~min}^{-1}$; $220 \mathrm{~nm}, 25{ }^{\circ} \mathrm{C} ; t_{\mathrm{R}}$ (major) $=13.7 \mathrm{~min}, t_{\mathrm{R}}($ minor $)=12.6 \mathrm{~min} .{ }^{1} \mathrm{H}$ NMR (400 MHz, DMSO) $\delta=7.39$ (ddd, $J=11.4,8.5,5.8 \mathrm{~Hz}, 1 \mathrm{H}$ ), $7.20-7.10(\mathrm{~m}, 1 \mathrm{H}), 5.24(\mathrm{~d}, J=19.1 \mathrm{~Hz}, 1 \mathrm{H}), 5.06(\mathrm{dd}, J=54.9$, $6.3 \mathrm{~Hz}, 1 \mathrm{H}$ ), 2.61 (ddd, $J=15.6,9.5,5.2 \mathrm{~Hz}, 1 \mathrm{H}), 2.47-2.26$ (m, 1H), 1.96-1.49 (m, 3H) ppm. ${ }^{13} \mathrm{C}$ NMR (101 MHz, DMSO) $\delta=$ 212.33, 163.39, 140.65, 129.71, 129.63, 115.63, 115.23, 71.68, $57.85,41.93,30.56,28.57,24.37,23.76 \mathrm{ppm}$.

(2S,1'R)-2-(Hydroxy(phenyl)methyl)cyclohexan-1-one (40). Reaction time: 48 h; yield: 49\%; white solid. Enantiomeric excess: $97 \%$, determined by HPLC with a Chiralpack OD-H

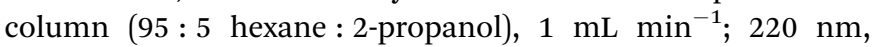
$25{ }^{\circ} \mathrm{C} ; t_{\mathrm{R}}$ (major) $=11.4 \mathrm{~min}, t_{\mathrm{R}}$ (minor) $=14.7 \mathrm{~min} .{ }^{1} \mathrm{H} \mathrm{NMR}$ (400 MHz, DMSO): $\delta=7.35-7.22(\mathrm{~m}, 5 \mathrm{H}), 5.19(\mathrm{~d}, J=4.3 \mathrm{~Hz}$, $1 \mathrm{H}), 4.93(\mathrm{dd}, J=8.3,4.3 \mathrm{~Hz}, 1 \mathrm{H}), 2.60(\mathrm{td}, J=8.4,5.4 \mathrm{~Hz}, 1 \mathrm{H})$, 2.45-2.23 (m, 2H), 1.83-1.64 (m, 3H), 1.56-1.43 (m, 2H), 1.18 (ddd, $J=12.5,8.8,4.0 \mathrm{~Hz}, 1 \mathrm{H}) \mathrm{ppm} .{ }^{13} \mathrm{C} \mathrm{NMR}(101 \mathrm{MHz}$, DMSO): $\delta=212.49,144.45,128.86,128.03,127.82,72.50,58.73$, 41.87, 30.70, 28.66, $23.68 \mathrm{ppm}$.

$\left(2 S, 1^{\prime} R\right)$-2-(Hydroxy(phenyl)methyl)cyclohexan-1-one (4p). Reaction time: 48 h; yield: $36 \%$; white solid. Enantiomeric excess: $97 \%$, determined by HPLC with a Chiralpack AD-H

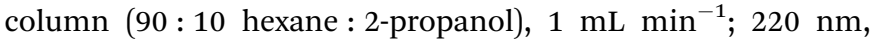
$25{ }^{\circ} \mathrm{C} ; t_{\mathrm{R}}$ (major) $=14.7 \mathrm{~min}, t_{\mathrm{R}}$ (minor) $=17.0 \mathrm{~min} .{ }^{1} \mathrm{H} \mathrm{NMR}$ (400 MHz, DMSO): $\delta=7.92-7.86(\mathrm{~m}, 1 \mathrm{H}), 7.83$ (s, 1H), 7.55-7.46 $(\mathrm{m}, 1 \mathrm{H}), 5.11(\mathrm{~d}, J=8.2 \mathrm{~Hz}, 1 \mathrm{H}), 2.72(\mathrm{td}, J=8.6,5.4 \mathrm{~Hz}, 1 \mathrm{H})$, 2.48-2.30 (m, 1H), 1.84-1.71 (m, 2H), 1.65 (ddd, $J=6.8,4.9$, $2.6 \mathrm{~Hz}, 1 \mathrm{H}), 1.50$ (ddd, $J=13.4,7.7,4.4 \mathrm{~Hz}, 1 \mathrm{H}) \mathrm{ppm} .{ }^{13} \mathrm{C} \mathrm{NMR}$ (101 MHz, DMSO): $\delta=212.45,141.98,133.59,133.35,128.69$, 128.48, 128.43, 126.97, 126.61, 126.45, 126.09, 124.69, 72.62, $58.57,42.28,30.85,28.64,27.40,25.25,23.81$ ppm.

(2S,1'R)-2-(Hydroxy-(4-nitro-phenyl)methyl)cyclopentan-1-

one (4t). Reaction time: 48 h; yield: $83 \%$; light yellow solid. Enantiomeric excess: 64\%, determined by HPLC with a Chiralpack AS-H column (70: 30 hexane : 2-propanol), $1 \mathrm{~mL} \mathrm{~min}^{-1}$; $254 \mathrm{~nm}, 25{ }^{\circ} \mathrm{C} ; t_{\mathrm{R}}$ (major) $=11.2 \mathrm{~min}, t_{\mathrm{R}}($ minor $)=23.2 \mathrm{~min} .{ }^{1} \mathrm{H}$ NMR (400 MHz, DMSO) $\delta=8.19(\mathrm{t}, J=6.9 \mathrm{~Hz}, 2 \mathrm{H}), 7.58(\mathrm{dd}, J=$ $37.9,8.2 \mathrm{~Hz}, 2 \mathrm{H}), 5.72(\mathrm{~s}, 1 \mathrm{H}), 5.19(\mathrm{~s}, 1 \mathrm{H}), 2.45$ (s, 1H), 2.30-2.19 $(\mathrm{m}, 1 \mathrm{H}), 2.14-2.00(\mathrm{~m}, 1 \mathrm{H}), 1.91$ (dd, $J=12.7,8.2 \mathrm{~Hz}, 1 \mathrm{H}), 1.80-$ $1.51(\mathrm{~m}, 3 \mathrm{H}) \mathrm{ppm} .{ }^{13} \mathrm{C}$ NMR (101 MHz, DMSO) $\delta=218.70$, 153.93, 147.27, 127.77, 124.15, 72.01, 55.96, 26.24, 22.86, $21.08 \mathrm{ppm}$.

$\left(2 S, 1^{\prime} R\right)$-4-Hydroxy-4-(4-nitrophenyl)pentan-3-one

(4u). Reaction time: $48 \mathrm{~h}$; yield: $88 \%$; light yellow solid. Enantiomeric excess: $75 \%$, determined by HPLC with a Chiralpack AS-H

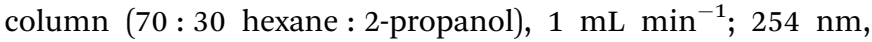
$25{ }^{\circ} \mathrm{C} ; t_{\mathrm{R}}$ (major) $=10.4 \mathrm{~min}, t_{\mathrm{R}}($ minor $)=11.0 \mathrm{~min} .{ }^{1} \mathrm{H} \mathrm{NMR}$ (400 MHz, DMSO) $\delta=8.21(\mathrm{dd}, J=11.3,5.0 \mathrm{~Hz}, 1 \mathrm{H}), 7.64$ (dd, $J$ $=6.4,2.3 \mathrm{~Hz}, 1 \mathrm{H}), 5.85-5.69(\mathrm{~m}, 1 \mathrm{H}), 5.25-4.73(\mathrm{~m}, 1 \mathrm{H}), 2.83-$ $2.72(\mathrm{~m}, 1 \mathrm{H}), 2.49(\mathrm{dd}, J=14.5,6.0 \mathrm{~Hz}, 1 \mathrm{H}), 2.19(\mathrm{~d}, J=15.3 \mathrm{~Hz}$, $1 \mathrm{H}), 0.92(\mathrm{t}, J=7.2 \mathrm{~Hz}, 1 \mathrm{H}), 0.83(\mathrm{~d}, J=6.9 \mathrm{~Hz}, 1 \mathrm{H}), 0.72(\mathrm{~d}, J=$ $7.0 \mathrm{~Hz}, 1 \mathrm{H}) \mathrm{ppm} .{ }^{13} \mathrm{C}$ NMR (101 MHz, DMSO) $\delta=209.51,152.37$, 147.69, 127.91, 124.19, 72.52, 52.17, 36.74, 8.34 ppm.

$\left(2 S, 1^{\prime} R\right)-4-H y d r o x y-4-(4-n i t r o p h e n y l) b u t a n-2-o n e$ (4v). Reaction time: $48 \mathrm{~h}$; yield: 95\%; light yellow solid. Enantiomeric excess: $22 \%$, determined by HPLC with a Chiralpack AS-H column (70:30 hexane : 2-propanol), $1 \mathrm{~mL} \min ^{-1} ; 254 \mathrm{~nm}$, $25{ }^{\circ} \mathrm{C} ; t_{\mathrm{R}}$ (major) $=12.8 \mathrm{~min}, t_{\mathrm{R}}($ minor $)=15.5 \mathrm{~min} .{ }^{1} \mathrm{H} \mathrm{NMR}$ (400 MHz, DMSO): $\delta=8.22(\mathrm{t}, J=14.5 \mathrm{~Hz}, 2 \mathrm{H}), 7.65(\mathrm{~d}, J=$ $8.2 \mathrm{~Hz}, 2 \mathrm{H}), 5.72(\mathrm{~d}, J=4.7 \mathrm{~Hz}, 1 \mathrm{H}), 5.16$ (dd, $J=11.6,5.9 \mathrm{~Hz}$, $1 \mathrm{H}), 2.76(\mathrm{~d}, J=6.5 \mathrm{~Hz}, 2 \mathrm{H}), 2.15(\mathrm{~s}, 3 \mathrm{H}) \mathrm{ppm} .{ }^{13} \mathrm{C}$ NMR (101 MHz, DMSO): $\delta=206.77,153.70,146.98,127.49$, 123.83, 68.57, 52.84, 30.87 ppm.

\section{Conflicts of interest}

There are no conflicts to declare.

\section{Acknowledgements}

This study was funded by the National Natural Science Foundation of China (No. 21174052) and the Natural Science Foundation of Jilin Province of China (No. 20160101311JC and 20170101105JC).

\section{References}

1 (a) B. List, R. A. Lerner and C. F. Barbas, J. Am. Chem. Soc., 2000, 122, 2395; (b) A. Moyano and R. Rios, Chem. Rev., 2011, 111, 4703.

2 Z. Tang, F. Jiang, L. Yu, X. Cui, L. Gong, A. Mi, Y. Jiang and Y. Wu, J. Am. Chem. Soc., 2003, 125, 5262.

3 X. R. Huang, Q. Liu, J. Wang, J. A. Xiao and H. Yang, Tetrahedron: Asymmetry, 2014, 25, 1590.

4 S. Saha and J. N. Moorthy, Tetrahedron Lett., 2010, 51, 912.

5 M. Gruttadauria, F. Giacalone and R. Noto, Adv. Synth. Catal., 2009, 351, 33.

6 For examples, see:(a) N. Mase, Y. Nakai, N. Ohara, H. Yoda, K. Takabe, F. Tanaka and C. F. Barbas, J. Am. Chem. Soc., 2006, 128, 734; (b) N. Mase, K. Watanabe, H. Yoda, K. Takabe, F. Tanaka and C. F. Barbas, J. Am. Chem. Soc., 2006, 128, 4966; (c) Y. Hayashi, T. Sumiya, J. Takahashi, H. Gotoh, T. Urushima and M. Shoji, Angew. Chem., Int. Ed., 2006, 45, 958; (d) Y. Y. Wu, Y. Z. Zhang, M. L. Yu, G. Zhao and S. W. Wang, Org. Lett., 2006, 8, 4417; (e) D. Font, C. Jimeno and M. A. Pericàs, Org. Lett., 2006, 8, 4653; (f) V. Maya, M. Raj and V. K. Singh, Org. Lett., 2007, 9, 2593; $(g)$ X. Wu, Z. Jiang, H. M. Shen and X. Lu, Adv. Synth. Catal., 2007, 349, 812.

7 D. C. Rideout and R. Breslow, J. Am. Chem. Soc., 1980, 102, 7816.

8 For examples, see:(a) N. Winterton, Chemistry for sustainable technologies: A foundation, RSC Publisher, 2010; (b) M. Lancaster, Green chemistry: An introductory text, RSC Publisher, 2010; (c) A. Corma, D. Das, H. Garćıa and A. Leyva, J. Catal., 2005, 229, 322; (d) S. Rostamnia and E. Doustkhah, RSC Adv., 2014, 4, 28238.

9 For examples, see:(a) M. Benaglia, M. Cinquini, F. Cozzi, A. Puglisi and G. Celentano, Adv. Synth. Catal., 2002, 344, 533; (b) M. Benaglia, A. Puglisi and F. Cozzi, Chem. Rev., 2003, 103, 3401; (c) F. Cozzi, Adv. Synth. Catal., 2006, 348, 1367; (d) M. Gruttadauria, F. Giacalone, A. M. Marculescu, P. Lo Meo, S. Riela and R. Noto, Eur. J. Org. Chem., 2007, 
28, 4688; (e) A. Lu, D. Moatsuo, D. A. Longbottom and R. K. O'Reilly, Chem. Sci., 2013, 4, 965; (f) F. Y. Hu, G. H. Du, L. Ye, Y. T. Zhu, Y. Wang and L. M. Jiang, Polymer, 2016, 102, 33.

10 For the review of catalyst-supported, see:(a) D. Font, A. Bastero, S. Sayalero, C. Jimeno and M. A. Pericas, Org. Lett., 2007, 9, 1943; (b) E. Alza, C. Rodriguez-Escrich, S. Sayalero, A. Bastero and M. A. Pericas, Chem.-Eur. J., 2009, 15, 10167; (c) P. Riente, C. Mendoza and M. A. Pericas, J. Mater. Chem., 2011, 21, 7350; (d) X. Y. Fan, E. Alza and M. A. Pericas, RSC Adv., 2012, 2, 6164; (e) P. Riente, J. Yadav and M. A. Pericas, Org. Lett., 2012, 14, 3668; $(f)$ A. M. Caminade, A. Ouali, M. Keller and J. P. Majoral, Chem. Soc. Rev., 2012, 41, 4113; $(g)$ B. Rasmussen and J. B. Christensen, Org. Biomol. Chem., 2012, 10, 4821; (h) L. Vaquer, P. Riente, X. Sala, S. Jansat, J. Benet-Buchholz, A. Llobet and M. A. Pericas, Catal. Sci. Technol., 2013, 3, 706.

11 J. W. Lee, T. Mayer-Gall, K. Opwis, C. E. Song, J. S. Gutmann and B. List, Science, 2013, 341, 1225.

12 G. Cooke and V. M. Rotello, Chem. Soc. Rev., 2002, 31, 275.

13 (a) Y. Zhang, W. Wang, Q. Li, Q. B. Yang, Y. X. Li and J. S. Du, Talanta, 2015, 141, 33; (b) W. Wang, Y. Zhang, Q. B. Yang, M. D. Sun, X. L. Fei, Y. Song, Y. M. Zhang and Y. X. Li, Nanoscale, 2013, 5, 4959.

14 Q. Li, Y. Li, J. D. Wang, Y. J. Lin, Z. L. Wei, H. F. Duan, Q. B. Yang, F. Q. Bai and Y. X. Li, New J. Chem., 2018, 42, 827.
15 R. Wang, Z. L. Wei, J. Guo, Y. S. Feng, E. J. Xu, H. F. Duan, Y. J. Lin, Q. B. Yang, J. S. Du and Y. X. Li, Chem. Res. Chin. Univ., 2018, 34, 180.

16 (a) C. Jaume, C. Josep, M. M. Marcial and V. Adelina, Tetrahedron: Asymmetry, 2002, 13, 1551; (b) K. Liu, D. Häussinger and W. D. Woggon, Synlett, 2007, 14, 2298; (c) S. A. Anton, D. A. Alexei, A. M. Olga, N. S. Evgenii, S. O. Boris, A. N. Ivan and P. B. Irina, Molecules, 2013, 18, 2096.

17 S. Guizzetti, M. Benaglia, L. Pignataro and A. Puglisi, Tetrahedron: Asymmetry, 2006, 17, 2754.

18 Y. Zhang, Rreparation and properties of optical chemosensing materials based on rhodamine and naphthalimide, Chem. Dept. Jilin Univ., Changchun, 2015.

19 L. Ding, T. Lee and C. H. Wang, J. Controlled Release, 2005, $102,395$.

20 (a) Q. B. Si, Q. Wen, Q. B. Yang, Y. Song and Y. X. Li, Chem. Res. Chin. Univ., 2017, 33, 1012; (b) W. P. Huang, J. R. Chen, X. Y. Li, Y. J. Cao and W. J. Xiao, Can. J. Chem., 2007, 85, 208. 21 (a) S. P. Zhang, X. K. Fu and X. D. Fu, Tetrahedron Lett., 2009, 50, 1173; (b) H. Tian, J. L. Gao, H. Xu, L. Y. Zheng, W. B. Huan, Q. W. Liu and S. Q. Zhang, Tetrahedron: Asymmetry, 2011, 22, 1074; (c) Y. Li, Q. C. Yang, X. Y. Xu, Y. Zhou, J. F. Bai, F. Y. Wang and L. X. Wang, Can. J. Chem., 2011, 89, 1312; (d) B. H. Xie, W. Li, Y. Liu, H. H. Li, Z. Guan and Y. H. He, Tetrahedron, 2012, 68, 3160; (e) S. Li, C. L. Wu, X. Q. Long, X. K. Fu, G. D. Chen and Z. J. Liu, Catal. Sci. Technol., 2012, 2, 1068. 